\title{
Examine of Mobbing via Humour Styles of Lecturers at Schools of Physical Education and Sport
}

\author{
Recep Cengiz ${ }^{1, *}$, Hakan Sunay ${ }^{2}$, Onur Mutlu Yasar ${ }^{3}$ \\ ${ }^{1}$ Faculty of Sport Sciences, Celal Bayar University, Turkey \\ ${ }^{2}$ Faculty of Sport Sciences, Ankara University, Turkey \\ ${ }^{3}$ School of Physical Education and Sport, Kastamonu University, Turkey
}

Copyright $\odot 2018$ by authors, all rights reserved. Authors agree that this article remains permanently open access under the terms of the Creative Commons Attribution License 4.0 International License

\begin{abstract}
The aim of the study was to examine the mobbing via humour of the lecturers at Schools of Physical Education and Sport. The sample of the study consisted of 470 lecturers dutied at those schools. In order to analyze the lecturers' perception levels about mobbing via humour behaviours, the "Scale of Humour Behaviours" was used. T-test and One Way ANOVA were used to determine whether the lecturers' humour styles differ or not according to independent variables. The data showed that the lowest average point was in the group aged 22-32 on average rather than the other age groups in the sub-dimension of Rejecting and Sarcastic Humour Styles $(\mathrm{p}<0.05)$. As a result, the relevant lecturers in the low age group were more interested in positive humour styles such as affirmative social humour although they were exposed to rejecting and sarcastic humour styles from time to time. When the lecturers have social humour styles and use these humours in a positive way, they will contribute to run more properly and to make more constructive decisions in favour of students in the process of having terminal behaviours which is a reason for having universities.
\end{abstract}

Keywords Lecturer, Humour, Mobbing, Physical Education, Sport, University

\section{Introduction}

The concept of violence, a concept that can be evaluated together with the history of humanity, can only be considered as physical violence if it is not widely thought, but violence in a broad sense; rude behavior, disorganization, emotional humiliation, etc. [35]. Violence is defined by the World Health Organization as "the exercise of physical enforcement, use of force or threat for cause, death, injury, psychological damage, developmental disorder, or cause to be committed to another person, group or community" [36]. According to the most common classification in the sources, violence is divided into four main groups as physical, psychological, sexual and economical. Mobbing is an important social problem experienced at both public and private sectorial enterprises. This occurs as behaviors such as humiliating sufferer, giving a nickname, not listening, casting aspersion, making innuendos, continuously following, making discrimination, threatening, giving insignificant duties, giving extra works, obtaining authorities and opportunities, deliberatively giving wrong information, despising abilities and achievements [1]. Many researches about this topic have the common point that mobbing causes mental, emotional and social problems such as stress, depression, lack of communication, conflict, burn-out and work no satisfaction in each field of social life [2, 3, 4, 5]. Although psychological violence is thought to originate from external factors, a close relationship between the behavioral disorders that negatively affect humor can be inevitable when triggered by personal events, unrequited demands or unrealized expectations that are triggered by one's inner world. In this process unhealthy communication, attacks to social relations, dignity, life and work quality as well as any practice of humour method are considered to be unaccepted behaviours within the concept of organizational relations. According to Martin [7], the humour concept is regarded as a personal characteristic and social case [8], the researchers $[8,9,10,11,12,13,14]$ from different fields regard this concept emphasize that humour expresses negative situations as a communication tool even if humour generally has a positive meaning. This different process is based on for which aims the person uses humour.

Karagözoğlu [15] stated that humour which makes life much more colourful and amusing can be used in a tolerant way and in a prejudicial and hurtful by an individual as well. Martin et al. [7] informed that incompatible and negative styles of humour are aggressive and self-destructive. The aggressive humour style means using 
humour about other people inappropriately for the society to fulfill their own needs regarding superiority and pleasure. This humour style contains ridiculing, taking the mickey, criticizing or humiliating other people. People, who perform the aggressive humour method, use it in ridicule, verbal abuse, wipe, humiliation, sex or race-contented style [16]. These behaviors create an environment presenting deficiency and inability feelings for victims. A victim thinks himself as an undesired person. Lecturers' behaviours directly or indirectly affect education when their behaviors change into ridicule, attrition, belittlement or disparagement at Schools of Physical Education and Sport. In terms of in-school communication and interaction, it is important how lecturers say to each other and what they do rather than what to say. In this regard, humour is an instrument [17]. Also, positive humour usage will contribute to healthy communication, work satisfaction and organization culture during interactions between managers-lecturers, managers-employees and

lecturers-students.

This study is of great importance since it creates awareness about the topic in the lecturers at each level and shows negative effects of the lecturers' mobbing actions via humour on teaching and training quality as well as their academic careers. In this context, it is necessary to determine the humorous behaviors that can contribute to the elimination or control of psychological violence, even if the expected result is not fully achieved. Moreover, when the acute and long-term effects of psychological violence are taken into consideration, the research that has been done in this sense is the foreground. Hereby, this research aimed to investigate whether the lecturers working at schools of physical education and sport were exposed to mobbing via humour.

\section{Method}

\section{Research Model}

The research was of a descriptive study with a screening model which aimed to analyze the perceptions of Lecturers at School of Physical Education and Sport about mobbing via humour behaviors.

\section{Research Group}

The sample of the research was applied to 500 lecturers at School of Physical Education and Sport. Turkish universities in Adıyaman, Ağrı İbrahim Ceçen, Ahi Evran, Aksaray, Ankara, Ankara Gazi, Atatürk, Balıkesir, Batman, Celal Bayar, Dicle, Dumlupınar, Erciyes, Firat, Erzincan, Gaziantep, Harran, İstanbul, İnönü, Kahramanmaraş Sütçü İmam, Kastamonu, Karamanoğlu Mehmet Bey, Kırıkale, Mustafa Kemal, Kocatepe, Manisa, Marmara, Sarıkamış, Selçuk, Trabzon and Uludağ Universities in the academic year 2013-2014, 479 questionnaires were included in the study while excluding the missing and inaccurate questionnaires. Studies conducted by Krejcie and Morgan (1970) show that the maximum limit for a tolerable error of 0.05 for the sample size corresponding to the volume of the universe was determined to be 500 participants, based on the rate of detection of the findings [37]. For this reason, this number has been tried to be reached in the study. Moreover, according to Yazicioglu and Erdoğan (2004), the number of samples required for the highest number of universe groups is 384. Accordingly, the number of participants in the study group was considered sufficient. In the study, data collection method was used easily [38]. In this method, the researcher presents the participant's data collection tool that he thinks is included in the study group and attains it and wants to participate on a voluntary basis.

\section{Data Collection Tools}

In the research, the "Scale of Humour Behaviours" developed by Cemaloglu et al. (2013) was firstly done to determine how mobbing via humour behaviors was effective as well as the lecturers' personal information. There are 30 items in the scale.

Table 1. The sub-dimensions of mobbing via humour

\begin{tabular}{|c|c|c|}
\hline Sub-Dimension & $\begin{array}{c}\text { Numbers of } \\
\text { Question }\end{array}$ & Question Number \\
\hline $\begin{array}{c}\text { Sarcastic Humour } \\
\text { Style }\end{array}$ & 8 & 23.24 .25 .26 .27 .28 .29 .30 \\
\hline $\begin{array}{c}\text { Productive-Social } \\
\text { Humour Style }\end{array}$ & 9 & 14.15 .16 .17 .18 .19 .20 .21 .22 \\
\hline $\begin{array}{c}\text { Affirmative } \\
\text { Humour Style }\end{array}$ & 5 & 9.10 .11 .12 .13 \\
\hline $\begin{array}{c}\text { Rejecting Humour } \\
\text { Style }\end{array}$ & 5 & 1.2 .3 \\
\hline Non-Humour Style & 3 & \\
\hline
\end{tabular}

Each item was ranked using a 5-interval scale changing between "Never Agree" and "Completely Agree". In order to determine the reliability of the scale, the Cronbach Alpha reliability coefficient was given. Towards the statistics, the Cronbach Alpha values were found to be .94 for the Sarcastic Humour Style, .92 for the Productive-Social Humour Style, .864 for the Affirmative Humour Style, .85 for the Rejecting Humour Style and .89 for the Non-Used Humour Style. The estimated reliability coefficient was .81 for the scale.

\section{Data Analysis}

In descriptive analysis of data, frequency, percentage, arithmetical average and standard deviation analyses were performed. T-test was used to find out whether the lecturers' humour styles changed in accordance with age, gender and marital status. Variance analysis (ANOVA) was also used to find out whether their situations changed in title variables. SPSS 20.0 package programs were used in all 
statistical estimations.

\section{Results}

In this chapter, the findings regarding the demographical information of the students included in the sample group were analyzed; the effects of mobbing on social support perceptions were researched.

Table 2. Lecturers' demographical information

\begin{tabular}{|c|c|c|c|}
\hline Characteristics & Groups & $\mathrm{N}$ & $\%$ \\
\hline \multirow{4}{*}{ Age } & $22-32$ & 71 & 14,8 \\
\hline & $33-43$ & 174 & 36,3 \\
\hline & +44 & 243 & 48,9 \\
\hline & Total & 479 & 100 \\
\hline \multirow{2}{*}{ Gender } & $\begin{array}{l}\text { Female } \\
\text { Male }\end{array}$ & $\begin{array}{c}90 \\
389\end{array}$ & $\begin{array}{l}18,8 \\
81,2\end{array}$ \\
\hline & Total & 479 & 100 \\
\hline \multirow{3}{*}{ Marital Status } & Married & 399 & 83,3 \\
\hline & Single & 80 & 16,7 \\
\hline & Total & 479 & 100 \\
\hline \multirow{7}{*}{ Title } & Instructor & 82 & 17,1 \\
\hline & Lecturer & 168 & 35,1 \\
\hline & Research Assistant & 99 & 20,7 \\
\hline & Assistant Professor & 92 & 19,2 \\
\hline & $\begin{array}{l}\text { Associate } \\
\text { Professor }\end{array}$ & 24 & 5,0 \\
\hline & Professor & 14 & 2,9 \\
\hline & Total & 479 & 100 \\
\hline
\end{tabular}

One hundred and fourth three of the lecturers participated in the research was aged 44 and over, 71 of them was between 22-32 years. The research group consisted of 389 males and 90 females. When looking at the marital status of the lecturers, 399 of them was married, 80 of them were single. When the titles of the research group were examined, 168 of them were lecturers and 14 of them were professors.

Looking at Table 3, the lecturers' frequency, average and standard deviation values were given in accordance with the age groups. In the Non-Humour Style from the sub-dimensions of Mobbing Scale, the group with the lowest average value was the group aged between 22-32 rather than the other age groups $(X=2.49 \pm 1.10)$. As another sub-dimension, in the Rejecting Humour Style, the group with the lowest average value was also the group aged between 22-32 rather than the other age groups $(X=2.10 \pm 0.94)$. In the sub-dimension of
Affirmative Humour Style, the group with the lowest average value was also the group aged 33-43 $(\mathrm{X}=3.05 \pm 0.82)$ than the other age groups. In the Productive-Social Humour Style, the group with the lowest average value was also the group aged 33-43 $(X=2.67 \pm 0.81)$ than the other age groups. Finally, the group with the lowest average value was also the group aged 22-32 ( $\mathrm{X}=2.07 \pm 0.80)$ than the other age groups when the sub-dimension of Sarcastic Humour Style was examined.

Table 3. Lecturers' frequency, mean and standard deviation (SD) values in accordance with age variable

\begin{tabular}{|c|c|c|c|c|}
\hline Sub-dimensions & Age & $\mathrm{N}$ & Mean & SD \\
\hline \multirow{4}{*}{ Non-Humour Style } & $22-32$ & 71 & 2.49 & 1.10 \\
\hline & $33-43$ & 174 & 2.67 & 1.09 \\
\hline & +43 & 234 & 2.69 & 0.92 \\
\hline & Total & 479 & 2.65 & 1.01 \\
\hline \multirow{4}{*}{$\begin{array}{l}\text { Rejecting Humour } \\
\text { Style }\end{array}$} & $22-32$ & 71 & 2.10 & 0.94 \\
\hline & $33-43$ & 174 & 2.56 & 0.88 \\
\hline & +43 & 234 & 2.51 & 0.86 \\
\hline & Total & 479 & 2.47 & 0.89 \\
\hline \multirow{4}{*}{$\begin{array}{c}\text { Affirmative Humour } \\
\text { Style }\end{array}$} & $22-32$ & 71 & 3.11 & 0.82 \\
\hline & $33-43$ & 174 & 3.05 & 0.82 \\
\hline & +43 & 234 & 3.10 & 0.76 \\
\hline & Total & 479 & 3.08 & 0.79 \\
\hline \multirow{4}{*}{$\begin{array}{l}\text { Productive-Social } \\
\text { Humour Style }\end{array}$} & $22-32$ & 71 & 2.74 & 0.82 \\
\hline & $33-43$ & 174 & 2.67 & 0.81 \\
\hline & +43 & 234 & 2.78 & 0.80 \\
\hline & Total & 479 & 2.73 & 0.81 \\
\hline \multirow{4}{*}{$\begin{array}{c}\text { Sarcastic Humour } \\
\text { Style }\end{array}$} & $22-32$ & 71 & 2.07 & 0.80 \\
\hline & $33-43$ & 174 & 2.28 & 0.71 \\
\hline & +43 & 234 & 2.25 & 0.78 \\
\hline & Total & 479 & 2.23 & 0.76 \\
\hline
\end{tabular}

According to Table 4, there was a statistically significant difference in the sub-dimension of Rejecting Humour Style in accordance with the lecturers' exposure situations to mobbing via humour $\left[\mathrm{F}_{(2-478)}=7.327 ; \mathrm{p}<0.05\right]$. Also, there was a statistically significant difference in the sub-dimension of Sarcastic Humour Style of the sample group $\left[\mathrm{F}_{(2-478)}=6.089 ; \mathrm{p}<0.05\right]$. Towards the results of Anova Test and Tukey test done to determine which group resulted in differences, the group with the lowest average value was the group aged 22-32 in the sub-dimensions of Rejecting $(X=2.10 \pm 0.94)$ and Sarcastic $(X=2.10 \pm 0.94)$ Humour Styles rather than the age groups $(\mathrm{p}<0.05)$. 
Table 4. ANOVA Test results of lecturers in accordance with age variable

\begin{tabular}{|c|c|c|c|c|c|c|}
\hline Sub-dimensions & & Sum of Squares & SD & Mean Square & $\mathrm{F}$ & $\mathrm{p}$ \\
\hline \multirow{3}{*}{ Non-Humour Style } & Between Groups & 2.329 & 2 & 1.164 & \multirow{3}{*}{1.123} & \multirow{3}{*}{0.326} \\
\hline & Within Groups & 493.638 & 476 & 1.037 & & \\
\hline & Total & 495.967 & 478 & & & \\
\hline \multirow{3}{*}{ Rejecting Humour Style } & Between Groups & 11.482 & 2 & 5.741 & \multirow{3}{*}{7.327} & \multirow{3}{*}{$0.001 *$} \\
\hline & Within Groups & 372.973 & 476 & 0.784 & & \\
\hline & Total & 384.455 & 478 & & & \\
\hline \multirow{3}{*}{ Affirmative Humour Style } & Between Groups & 0.343 & 2 & 0.171 & \multirow{3}{*}{0.269} & \multirow{3}{*}{0.764} \\
\hline & Within Groups & 302.679 & 476 & 0.636 & & \\
\hline & Total & 303.022 & 478 & & & \\
\hline \multirow{3}{*}{ Productive-Social Humour Style } & Between Groups & 1.283 & 2 & 0.641 & \multirow{3}{*}{0.972} & \multirow{3}{*}{0.379} \\
\hline & Within Groups & 314.159 & 476 & 0.660 & & \\
\hline & Total & 315.442 & 478 & & & \\
\hline \multirow{3}{*}{ Sarcastic Humour Style } & Between Groups & 2.326 & 2 & 1.163 & \multirow{3}{*}{6,089} & \multirow{3}{*}{0.048 * } \\
\hline & Within Groups & 278.724 & 476 & 0.586 & & \\
\hline & Total & 281.049 & 478 & & & \\
\hline
\end{tabular}

$* \mathrm{p}<0.05$

Looking at Table 5, there were no significant differences in the sub-dimensions of the scale in accordance with the gender variable $(\mathrm{p}>0.05)$.

Table 5. T- Test results of lecturers in accordance with gender variable

\begin{tabular}{|c|c|c|c|c|c|c|}
\hline Sub-dimensions & Gender & $\mathrm{N}$ & Mean & $\mathrm{SD}$ & $\mathrm{t}$ & $\mathrm{p}$ \\
\hline \multirow{2}{*}{ Non-Humour Style } & Female & 90 & 2.69 & 1.02 & \multirow{2}{*}{.392} & \multirow{2}{*}{.695} \\
\hline & Male & 389 & 2.64 & 1.01 & & \\
\hline \multirow{2}{*}{ Rejecting Humour Style } & Female & 90 & 2.50 & .92 & \multirow{2}{*}{.371} & \multirow{2}{*}{.711} \\
\hline & Male & 389 & 2.46 & .89 & & \\
\hline \multirow{2}{*}{ Affirmative Humour Style } & Female & 90 & 3.02 & .73 & \multirow{2}{*}{-.849} & \multirow{2}{*}{.396} \\
\hline & Male & 389 & 3.10 & .80 & & \\
\hline \multirow{2}{*}{ Productive-Social Humour Style } & Female & 90 & 2.61 & .87 & \multirow{2}{*}{-1.580} & \multirow{2}{*}{.115} \\
\hline & Male & 389 & 2.76 & .79 & & \\
\hline \multirow{2}{*}{ Sarcastic Humour Style } & Female & 90 & 2.18 & .69 & \multirow{2}{*}{-.742} & \multirow{2}{*}{.459} \\
\hline & Male & 389 & 2.25 & .78 & & \\
\hline
\end{tabular}

A statistically significant difference was observed in the social sub-dimension of the scale regarding that the ones were married or not as seen at Table $6\left[\mathrm{t}_{(477)}=-2.902 ; \mathrm{p}<0.05\right]$. The single ones had higher average points than the married ones.

Table 6. T- Test results of lecturers in accordance with marital status variable

\begin{tabular}{|c|c|c|c|c|c|c|}
\hline Sub-dimensions & Marital Status & $\mathrm{N}$ & Mean & $\mathrm{SD}$ & $\mathrm{t}$ & $\mathrm{p}$ \\
\hline \multirow{2}{*}{ Non-Humour Style } & Married & 399 & 2.64 & 1.01 & \multirow{2}{*}{-0.721} & \multirow{2}{*}{0.471} \\
\hline & Single & 80 & 2.73 & 1.05 & & \\
\hline \multirow{2}{*}{ Rejecting Humour Style } & Married & 399 & 2.47 & 0.88 & \multirow{2}{*}{0.334} & \multirow{2}{*}{0.739} \\
\hline & Single & 80 & 2.44 & 0.93 & & \\
\hline \multirow{2}{*}{ Affirmative Humour Style } & Married & 399 & 3.07 & 0.78 & \multirow{2}{*}{-0.690} & \multirow{2}{*}{0.491} \\
\hline & Single & 80 & 3.14 & 0.83 & & \\
\hline \multirow{2}{*}{ Productive-Social Humour Style } & Married & 399 & 2.69 & 0.77 & \multirow{2}{*}{-2.902} & \multirow{2}{*}{0.004} \\
\hline & Single & 80 & 2.97 & 0.94 & & \\
\hline \multirow{2}{*}{ Sarcastic Humour Style } & Married & 399 & 2.23 & 0.73 & \multirow{2}{*}{-0.463} & \multirow{2}{*}{0.644} \\
\hline & Single & 80 & 2.27 & 0.93 & & \\
\hline
\end{tabular}

No statistically significant difference was found in the sub-dimension of Social Humour Style in accordance with the title variable about the exposure situations of the sample group to mobbing via Humour when looking at Table 7 $\left[\mathrm{F}_{(5-478)}=3.590 ; \mathrm{p}>0.05\right]$. 
Table 7. ANOVA test results of lecturers according to title variable

\begin{tabular}{|c|c|c|c|c|c|c|}
\hline Sub-dimensions & & Sum of Squares & $\mathrm{SD}$ & Mean Square & $\mathrm{F}$ & $\mathrm{p}$ \\
\hline \multirow{3}{*}{ Non-Humour Style } & Between Groups & 10.652 & 5 & 2.130 & \multirow{3}{*}{2.076} & \multirow{3}{*}{.067} \\
\hline & Within Groups & 485.315 & 473 & 1.026 & & \\
\hline & Total & 495.967 & 478 & & & \\
\hline \multirow{3}{*}{$\begin{array}{c}\text { Rejecting } \\
\text { Humour Style }\end{array}$} & Between Groups & 4.987 & 5 & .997 & \multirow{3}{*}{1.243} & \multirow{3}{*}{.288} \\
\hline & Between Groups & 379.468 & 473 & .802 & & \\
\hline & Total & 384.455 & 478 & & & \\
\hline \multirow{3}{*}{ Affirmative Humour Style } & Between Groups & 5.665 & 5 & 1.133 & \multirow{3}{*}{1.802} & \multirow{3}{*}{.111} \\
\hline & Between Groups & 297.357 & 473 & .629 & & \\
\hline & Total & 303.022 & 478 & & & \\
\hline \multirow{3}{*}{ Productive-Social Humour Style } & Between Groups & 11.533 & 5 & 2.307 & \multirow{3}{*}{1.590} & \multirow{3}{*}{.303} \\
\hline & Between Groups & 303.909 & 473 & .643 & & \\
\hline & Total & 315.442 & 478 & & & \\
\hline \multirow{3}{*}{ Sarcastic Humour Style } & Between Groups & 3.371 & 5 & .674 & \multirow{3}{*}{1.149} & \multirow{3}{*}{.334} \\
\hline & Between Groups & 277.678 & 473 & .587 & & \\
\hline & Total & 281.049 & 478 & & & \\
\hline
\end{tabular}

\section{Discussion}

In this study, the perceptions of the lecturers working at the schools of physical education and sport about mobbing via humour behaviors were studied in accordance with age, gender, marital status and title variables. The findings of the research were given below.

Looking at the results of the study, mobbing is used for not accepting and refusing words and behaviors, rejecting and humiliating, depreciating, hurting others and making them upset. A statistically significant difference was found in the groups aged 22-32, 33-43 and 43-over in the sub-dimension of sarcastic humour style used for limitation relations and thinking one superior. According to these results, it can be said that the lecturers did not accept and refused negative humour attributes, expressions and behaviors aimed at ironizing, bullying, ridiculing and humiliating themselves. According to Cemaloğlu [18] the individuals who have this humour style use humour as a style including irony, bullying, ridicule, humiliation, sexuality and racism. In studies parallel with our findings $[7,8,9,19,20,21]$, there was a significant relation between age and mobbing. Özyer and Orhan [4] suggested mobbing the lecturers suffered from increased by the ages 36-40 and this effect decreased in the next years. Also, many researchers showed that old employers were exposed to mobbing less than the young employers and employers were exposed to more than their managers within the framework of the organizational positions [20]. This finding proves that the middle-aged group and the older ones were respected more and suffered from mobbing less depending on the patriarchal structure of Turkish society. However, the researchers concluded that the age factor was not a significant determinant $[21,22$,
$23,24,25]$.

There was not a significant difference in the gender variable of the scale sub-dimensions ( $p>0.05)$. In the field researches, when studying the relation between gender and mobbing, two different results were obtained. In studies parallel with our findings, gender was not an effective variable on one's own $[21,22,26]$. On the other hand, Martin's study [15] indicated that the males had higher points than the females in terms of aggressiveness and self-abuse. Yerlikaya [9] found that the high school male students' points from the sub-dimensions of Aggressive Humour and Self-Devastating Humour were higher than the girl students' points. Özkan [27] stated that the male students preferred aggressive humour more than the female students.

Çetin [10] indicated that the aggressive humour style was negatively related with the positive emotional goodness perception and positively related with the negative emotional goodness perception. Akkaya and Turan [28] stated that the Participatory Humour and Self-Developing Humour styles were used by the male students more. In studies supporting these findings $[10,19,26,30]$, there was a significant relation between gender and mobbing. These results could not show a clear idea about whether gender was an important variable. Even if this situation does not present any interaction between genders and mobbing situations exactly, it signs gender will have different effects on mobbing in social-cultural conditions and sectors.

A statistically significant difference was found in the productive social humour sub-dimension regarded as the positive humour styles in accordance with the marital status variable of the scale sub-dimensions $\left[\mathrm{t}_{(477)}=-2.902\right.$; $\mathrm{p}<0.05]$. The single ones had higher average points than 
the married ones. These data demonstrated that the single ones used humour for themselves and the others in order to create a positive communication environment respectfully gave importance to develop relations between them, preferred funny and comic experiences and even said humorous things about themselves [17]. The productive-social humour means the tendencies such as making jokes, telling funny stories and giving humorous speeches and facilitates human relations [31]. Moreover, they have habits such as saying comic things about themselves and ignoring themselves more to relieve the others [15]. In this way, the productive social humour is described as the characteristics of self-fulfilling, self-confident people. Martin (2007) explained that the social humour helped to create new relations or strengthen friendships and to solve conflicts by being a bridge between individuals and provided fulfillment by increasing creativity and productivity.

Some researches clarify the individuals with a high level of humour emotions as the ones having positive characteristics such as optimism, self-acceptance, self-confidence and independence $[19,22,30]$. These items support the findings of the study. In response to these data, the single ones' social environment and social lives are more different and flexible, their duties and responsibilities sometimes go wrong in their working institutions, which was given by the literature studies that the perception levels of mobbing were not important for the marital status $[24,32 ; 33]$. These findings do not comply with our study.

When examining Table 8 , the sample group did not show any significant difference in the exposure situations to mobbing via humour in accordance with the title variable. In other words, title is not an effective method in the lecturers' humorous practices. Ozdemir and Recepoğlu [24] noted that humour was an important and effective item in achieving the aims of any organization and there were not differences in the humour styles in accordance with the seniority variable. Furthermore, similar studies $[10,22,25,33,34]$ showed that humour maintains social relations, decreases work stress, individuals with humour sense generally have positive characteristics such as optimism, self-acceptance, self-confidence and independence. Like in the gender variable, there are different findings regarding the differences in the humour styles in accordance with the title variable $[5,18,29]$.

\section{Conclusions}

In conclusion, even though the lecturers with smaller ages involved in the research were exposed to the rejecting and sarcastic humour style in time, they were closer to the positive humour styles such as the affirmative social humour. In this sense, it can be said that the humorous approach in reaching the expected result will create an effective communication environment in the school and the classroom environment, contributing to the elimination of psychological violence. When the lecturers have social humour styles, the positive usage of humour will contribute to this process to run more properly and lead to make building decisions in favour of the students while trying to make the students acquire terminal behaviors as an existential reason of universities.

But since there is no way to determine the cause-and-effect relationship in the study, is it a consequence of the anger behavior, or why? There is no opportunity to answer. The fact that an instructor has caught the rhythm of humor in his life can be interpreted as having a vitality and rhythm in itself. The sense of humor is also an indication of the joy of living. In this context, it can be said that the humor used in the university environment does not have a humor to hide the personal worries and anxieties.

It is believed that this work will contribute to the understanding, control and supervision of the feelings of humor and psychological violence for educational institutions, lecturers, administrators and students. Based on the findings of the study and findings, the following proposals have been developed in line with the conclusions reached.

- It can be said that carrying out the programs aiming to give humor education to the instructors who have psychological violence problem in the direction of the study results will contribute to help the instructors to overcome the negative situations they live with less harmfulness.

- It may be useful to ensure participation of instructors who have psychological violence problems in recreational activities.

- Study because the sport science in universities includes a faculty or college teaching staff group, the work to be done in a wider range of teaching staff will be beneficial in enhancing healthy, productive, productive and qualified human power in academic life.

\section{REFERENCES}

[1] Mikkelsen E, Einarsen S 2002. Relationships between exposure to bullying at work and psychological and psychosomatic health complaints: the role of state negative affectivity and generalized self-efficacy. Scandinavian Journal of Psychology, 43: 397-405.

[2] Orhan U 2009. "Reasons and effects of psychological harassment (mobbing) applied to academicians: Mustafa Kemal University example". Master Thesis, Institute of Social sciences, Gaziosmanpaşa University, Tokat, Turkey.

[3] Gün H 2010 "Psychological harassment (mobbing) and productivity relationship". Journal of Key Productivity in Development, 22(254): 36-39. 
[4] Özyer K, Orhan U 2012. An empirical study of the mobbing applied to academicians. Ege Academic Review, 12(4): 511-518. İzmir.

[5] Mete AY 2013. Mobbing in higher education: practitioners, victims and audiences. International Journal of Social Science, 6(2): 977-993.

[6] Martin RA 2007. The Psychology of Humor: An Integrative Approach, Amsterdam: Elsevier

[7] Svebak S 2010. The sense of humor questionnaire: conceptualization and review of 40 years of findings in empirical research. Europe's Journal of Psychology, 6(3): 288-310.

[8] Teehan RE 2006. The relationship between emotional intelligence. Sense of humor and job satisfaction in masters of business students at a Midwestern university. Doctoral dissertation). Retrieved from ProQuest Dissertations and Theses database, (UMI No. 3215971).

[9] Yerlikaya Y 2007. "Examining the relationship between high school students' humor styles and styles of coping with stress". Master Thesis, Çukurova University, Institute of Social Sciences, Adana, Turkey.

[10] Cetin M 2009. The relationship between humor styles and job related affective well-being of employees among different sectors and the moderating effect of social climate. Master Thesis, Institute of Social Sciences, Marmara University, İstanbul, Turkey.

[11] Erözkan A 2009. Interpersonal relationship styles and humour styles of university students. Buca Faculty of Education Journal, 26: 56-66. İzmir

[12] Özdemir S, Sezgin F, Kaya Z, Recepoğlu E 2011. “The relationship between primary school teachers' coping styles with stress and humor styles". Educational Administration: Theory

[13] Cemaloğlu N, Recepoğlu E, Șahin F, Daşçı E, Köktürk O 2013." Development of the scale of humor behaviors: validity and reliability study". Journal of Turkish Educational Sciences, 10(4): 693-716.

[14] Karagözoğlu O 2009. "Relationship between primary school teachers' humor styles and burnout levels". Master Thesis, Institute of Social Science, Maltepe University, İstanbul, Turkey.

[15] Kazarian SS, Martin RA 2004. "Humor styles, personality, and well-being among Lebanese University students". European Journal of Personality, 18: 209-219.

[16] Loworn MG Humor in the home and in the classroom: the benefits of laughing while we learn. Journal of Education and Human Development, 2(1): 1-12.

[17] Cemaloğlu N 2011. Primary principals' leadership styles, school organizational health and workplace bullying. Journal of Educational Administration, 49(5): 495-512.

[18] Sepetçi C 2010. "Describing the humor styles of school administrators". Master Thesis, Institute of Social Sciences, Gaziosmanpaşa University, Tokat, Turkey.

[19] Ayan S 2011. Mobbing to research assistants at universities: Examples of Gazi, Kocaeli and Cumhuriyet University. Ege
Academic Review, 27: 1-18. İzmir.

[20] Comak E, Tunç B 2012. "Intimidation situation of elementary school teachers in elementary schools". Mersin University Journal of the Faculty of Education. 3(3): 197-208. Mersin.

[21] Hegney D, Tuckett A, Parker D, Eley R 2010. "Workplace violence: differences in perceptions of nursing work between those exposed and those not exposed: a cross-sector analysis". International Journal of Nursing Practice, 16: 188-202.

[22] Karcioğlu F, Çelik ÜH 2012. "Mobbing and influence on organizational commitment". Atatürk University Journal of Economics and Administrative Sciences, 26(1): 59-75. Erzurum.

[23] Mammadov E 2010. "Comparison of mobbing behaviors of teachers working in primary schools in Turkey and Azerbaijan". Master Thesis, Institute of Education Sciences, Gazi University, Ankara, Turkey.

[24] Özdemir S, Recepoğlu E 2010. "Organizational health and humor". In V. National Education Management Congress in Antalya, Turkey, 2010, Gazi Üniversitesi \& EYEDDER, pp. 219-229. Antalya.

[25] Öğretmen H. 2013. "Mobbing in effect on job satisfaction: A survey on teachers working in the province of Tarsus in Mersin province". Master Thesis, Institute of Social Sciences, Çağ University, Mersin, Turkey.

[26] Özkan H., I. 2008. "The influence of the sense of humor in the teachers and the students to the class atmosphere". Master Thesis, Institute of Social Sciences, Selçuk University, Konya, Turkey.

[27] Akkaya M, Turan S 2011. "Investigating the relationship between the classroom management skills of classroom teachers and humor styles". In Symposium: 20. National Educational Sciences Congress, Turkey, Pegem, İstanbul.

[28] Cimen B 2011. "Examination of the perceptions of classroom teachers who work in government and private schools on their ability to use humor in teaching process". Master Thesis, Institute of Social Sciences, Akdeniz University, Antalya, Turkey.

[29] Yilmaz K 2011. An analysis of humor styles of school administrators. The Inonu University Journal of the Faculty of Education, 12(1): 31-44. Malatya

[30] Vernon PA, Martin RA, Schermer JA, Mackie A 2008. A behavioral genetic investigation of humor styles and their correlations with the Big-5 personality dimensions. Personality and Individual Differences, 44: 1116-1125.

[31] Akşahin E 2012. "Examination of the levels of exposure to mobbing behaviors of primary school teachers in terms of socio-demographic variables": Istanbul Province Esenler District. Master Thesis, Institute of Social Sciences, Yeditepe University, İstanbul, Turkey

[32] Cemaloğlu N, Okçu V 2012. "The relationship between leadership styles of elementary school administrators and mobbing levels of teachers"'. Uşak University Journal of Social Sciences, 5(3): 214-239. Usak.

[33] Aksu T, Güneri B 2011. "Effect of teaching staff's exposure 
sensitivities on job alienation". E-International Journal of Educational Research, 2(4): 28-43.

[34] Kara H 2014. "The theoretical and applications explanation of manager's humor styles at practice status". Journal of History School, 7(17): 701-724. and Practice, 17(3): 405-428.

[35] Köknel, O. (2006), "Bireysel ve Toplumsal Şiddet”, İstanbul: Altın Yayınları, 5. Baskı: 20.
[36] World Health Organization: Violence and Health: Task Force on Violence and Health. Cenevre, WHO, 2002.

[37] Krejcie, R. V., \& Morgan, D. W. (1970). Determining sample size for research activities. Educational and psychological measurement, 30(3), 607-610.

[38] Yazıcı̆ğlu, Y. ve Erdoğan, S. (2004). Spss uygulamalı bilimsel araştırma yöntemleri. Ankara: Detay Yayıncılık. 